\title{
Saint Agnes of Bohemia: A Thirteenth-Century Iconoclast and the Enduring Legacy of Her Convent as a Sacred Space for Religious Art
}

\author{
J. David Puett ${ }^{1,2}$ (1)
}

check for updates

Citation: Puett, J. David. 2021. Saint Agnes of Bohemia: A ThirteenthCentury Iconoclast and the Enduring Legacy of Her Convent as a Sacred Space for Religious Art. Religions 12: 826. https://doi.org/10.3390/ rel12100826

Academic Editor: Hilaire Kallendorf

Received: 26 August 2021

Accepted: 27 September 2021

Published: 1 October 2021

Publisher's Note: MDPI stays neutral with regard to jurisdictional claims in published maps and institutional affiliations.

Copyright: (C) 2021 by the author. Licensee MDPI, Basel, Switzerland. This article is an open access article distributed under the terms and conditions of the Creative Commons Attribution (CC BY) license (https:/ / creativecommons.org/licenses/by/ $4.0 /)$.
College of Arts and Sciences, University of Georgia Athens, Athens, GA 30602, USA; puett@uga.edu 2 School of Medicine, University of North Carolina at Chapel Hill, Chapel Hill, NC 27516, USA

\begin{abstract}
Refusing to accept her expected role of becoming an item of negotiation in an arranged marriage to strengthen a political alliance, Agnes of Bohemia (1211-1282), daughter of King Přemysl Otakar I of Bohemia and Queen Constance of Hungary, chose to use her royal dowry to finance construction of the first hospital, convent, monastery, and church in Prague committed to the teachings of Saint Francis. Her youth was influenced by nuns providing her education, by a strong familial precedent in the support of churches and convents, and by religious contemporaries. Joining the fledging Franciscan movement, this remarkably well-educated and deeply committed woman entered as abbess of the convent in 1234, dedicating her life to poverty without endowment, devotion, and service to the sick and poor. Agnes was beatified by Pope Pius IX in 1874 and canonized by Pope John Paul II in 1989. Her legacy remains in Prague today with the Gothic convent she constructed now serving as a premiere museum devoted to the Medieval and Renaissance religious art of Prague and Central Europe. Thus, the original goal of building a sacred space for sisters in order to foster spiritual mediation has now been redirected to provide the public the opportunity to become immersed in ecclesiastical reflection viewing the works of artists such as Master Theodoric, the Master of Vyšší Brod, the Master of the Třebon Altarpiece, and others.
\end{abstract}

Keywords: Saint Agnes of Bohemia; Convent of Saint Agnes; Přemyslid dynasty; Prague; Master Theodoric; the Master of Vyšši Brod; Master of the Třeboň Altarpiece; Medieval and Renaissance Art of Central Europe

\section{Introduction}

\subsection{Overview of the Přmyslid Dynasty in Bohemia}

Thirteenth-century Central Europe was composed of a number of powerful kings and kingdoms, each vying with the others for territorial gain and political advantage. The Přemyslid Dynasty of Bohemia had humble beginnings as a tribe of Western Slavs around the area of Prague in the late ninth century. Dukes ruled with but two exceptions, one occurring in the eleventh century and the other in the twelfth century, when the Holy Roman Emperor appointed each as king. By conquering regions of Bohemia and controlling trade routes through and around Prague, the dynasty gradually expanded its hegemony over surrounding territories, increased its financial coffers, and gained in prestige and recognition.

The available historical documentation indicates that Bořivoj I (c. 852-c. 889), considered the progenitor of the Přemyslid dynasty, was the first Duke of Bohemia. It is noteworthy that, following their baptism by Bishop Methodius of Thessalonica (c. 815-c. 885), Agnes' ancestors, Duke Bořivoj I and his wife Saint Ludmila (c. 860-921), a patron saint of Bohemia, were responsible for the introduction of Christianity into Bohemia and the building of the first Christian church in the region. Their conversion occurred amid much opposition, and Christianity had, at most, a tenuous hold on the general population. Bořivoj and Ludmila had two sons, Spytihněv I (c. 875-915) and Vratislaus I (c. 888-921), who, respectively, 
served as the second and third Dukes of Bohemia. Vratislaus I married Drahomíra of Stodor (c. 880s-c. 935) in about 906, and they had two sons, Wenceslaus I (c. 911-935) and Boleslaus I (c. 909-c. 967), and several daughters.

Following the death of Vratislaus I, Drahomíra became regent for her sons, but the Bohemian nobles stipulated that the government must be shared with Ludmila, who proceeded to instill Christianity into her two grandsons, particularly Wenceslaus I, the first of the brothers to rule. The pagan beliefs of Drahomíra and her opposition to Ludmila's religious influence over Wenceslaus I and Boleslaus I led Drahomíra to order the assassination of her mother-in-law by two noblemen. Ludmila was canonized shortly thereafter. After serving as Duke of Bohemia for fourteen years, in 935 Wenceslaus I was killed in a coup in which his brother, Boleslaus I, was complicit ${ }^{1}$. Like his grandmother, Ludmila, Wenceslaus I, who became known as the Good King Wenceslaus, was canonized shortly after his death. The martyrdoms of Ludmila and Wenceslaus I were important in establishing strong ties between the Bohemian state and the Roman church (Thomas 1998, pp. 22-3; Klaniczay 2002, pp. 100-1).

After several centuries of rule by the Přemyslids, Otakar I (c. 1160-1230) became Duke of Bohemia in 1192. He was granted the title, King of Bohemia, by three kings of Germany ${ }^{2}$. This kingship continued through Otakar I's son, grandson, great-grandson, and great-great-grandson, with the House of Přemsyl ending its rule in 1306. A concise overview of the Přemyslid dynasty is available (Curta 2019).

\subsection{Aims to Be Addressed}

Medieval Bohemia was a strong patriarchal society that granted few, if any, concessions to the power of women, including princesses. Agnes (Figure 1) was in the vanguard of a small group of central European women, many of whom were related, who insisted on forging a life of their own choosing, using their royal funds for goals such as building and administering convents and hospitals. Moreover, these women were educated and contributed significantly to the arts and literature of central Europe. Specifically, the following questions will be addressed herein. (a) What were the motivating forces that led Agnes to refute her father, King Otakar I, King Frederick II of Germany, and other royal suitors to forego the life of a queen and instead use her royal dowry to construct a convent, hospital, church, and monastery, choosing a life of poverty without endowment, rather than one of relative comfort? (b) How did Agnes accomplish her goals, and what was the impact of her efforts on thirteenth-century Prague? (c) What serendipitous circumstances enabled the Saint Agnes Convent to survive the eight hundred years between the death of Saint Agnes and present? and (d) What relationship exists between the function of the original Saint Agnes Convent to its use in contemporary Prague as a sacred space for meditative Medieval and Renaissance religious art?

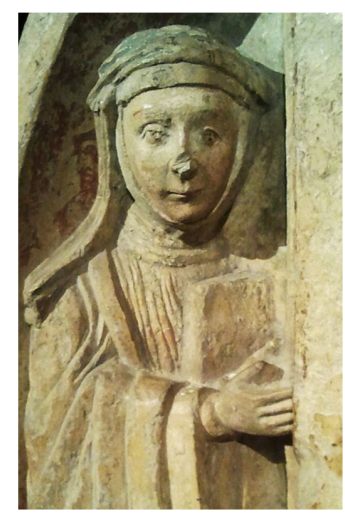

Figure 1. Bust of Agnes. Made in the 1220s by an unknown artist and located in Saint George Convent, Prague Castle. Downloaded from Wikimedia Commons: Attribution-Share Alike 4.0 International License. Author, Packare. 


\section{Birth and Education of a Bohemian Princess}

The last of nine children born in Prague to Otakar I and his second wife Constance of Hungary (c. 1180-1240) was Princess Agnes (1211-1282). When only three years of age, Agnes was sent with her older sister Anna (1204-1265) to the court of Henry the Bearded (1165-1238), who was married to the Duchess Hedwig of Silesia (1174-1243) and future Saint Hedwig of Andechs. Agnes was betrothed to Boleslaw (c. 1191-1210), the oldest son of Henry and Hedwig. From there, Agnes was placed with the Cistercian nuns of Trebnitz in Silesia for her education. Upon Boleslaw's early and untimely death, Agnes returned to Prague and then went to the Bohemian Premonstratensian convent of Doxony to continue her education. This convent was founded in 1143 by her aunt, Queen Gertrude of Merania (1185-1213). Meanwhile, Anna, betrothed to the Henry and Hedwig's second son, Henry II the Pious (c. 1196-1241), whom she later married in 1216, remained in Silesia and thus strengthened the ties between the Přemyslid and the Piast dynasties (Klaniczay 2002, p. 204).

Like other daughters of royalty, Agnes was, if suitable arrangements could be made, destined for marriage to a member of a neighboring court in order to make, enhance, or solidify a political alliance. Another path for such daughters was to join a convent, either by choice because of their religious leanings or because marriage arrangements failed to materialize. For example, of Agnes' six sisters and half-sisters that reached adulthood, one married a king, another married a count, two married dukes, one became a nun, and another, Wilhelmina of Bohemia, also known as Guglielma (1210-1281), embraced an alternative form of Christianity ${ }^{3}$.

Most of the young women from affluent families who entered a life of religion did so in one of the established wealthier Orders. The Franciscan doctrines that were in their infancy did not enter Central Europe until the early 1220s, and few women of royal birth would have chosen the austere life dictated by the Poor Clares.

In 1219, Otakar I was asked by Frederick II for his permission to betroth Agnes to his son, the Hohenstaufen prince, Henry VII (1211-1242). Pleased with the arrangement to strengthen ties with the powerful king, one year later Otakar I sent his daughter to the court of Leopold VI (1176-1230), Austrian Babenberger Duke, to receive training and an education for her role as a future queen. Although Leopold VI agreed to receive Agnes, he, unknown to Otakar I, wanted to marry his own daughter, Margaret (1204-1266), to Henry VII, who was also in residence in Vienna. Receiving a dispensation from Pope Honorius III (1150-1227, papacy 1216-1227), Frederick II annulled the contract for his son to marry Agnes, and Henry VII instead was wed to Margaret in 1225. Following Leopold VI's betrayal, Agnes returned to Prague and Otakar I, in his fury, declared war on Austria the following year. Austria prevailed in the conflict, and an angered Otakar I was forced to withdraw and plan another offensive, one however that failed to materialize.

In 1230 Otakar I died, and his eldest surviving son with Constance, Wenceslaus I (c. 1205-1253), assumed the throne. Similar to his father, Wenceslaus I was approached by Frederick II, now a widower, who requested a marriage with Agnes, but this union was to be for himself. Earlier, Agnes had refused overtures of a marriage with King Henry III of England (1207-1272), and now, at twenty years of age, made the decision not to marry, but instead dedicate herself to the early Franciscan movement, choosing a life of poverty, devotion, and caring for the sick and poor (Figure 2). This was a major decision for a young woman to reject an offer to become queen of the powerful kingdom of Germany, where she would have lived in relative comfort and prosperity, with one overriding responsibility, namely that of producing male heirs. Upon learning of Pope Gregory IX's (1145-1241, papacy 1227-1241) approval to receive Agnes into the Church, the two kings, Wenceslaus I and Frederick II, reluctantly agreed to accept Agnes' refusal of a marriage contract. Indeed, always anxious to thwart the ambitious Frederick II whenever possible, as the two were often in conflict over territory, Gregory IX was pleased to approve Agnes' request to seek a life of devotion and charitable work. 


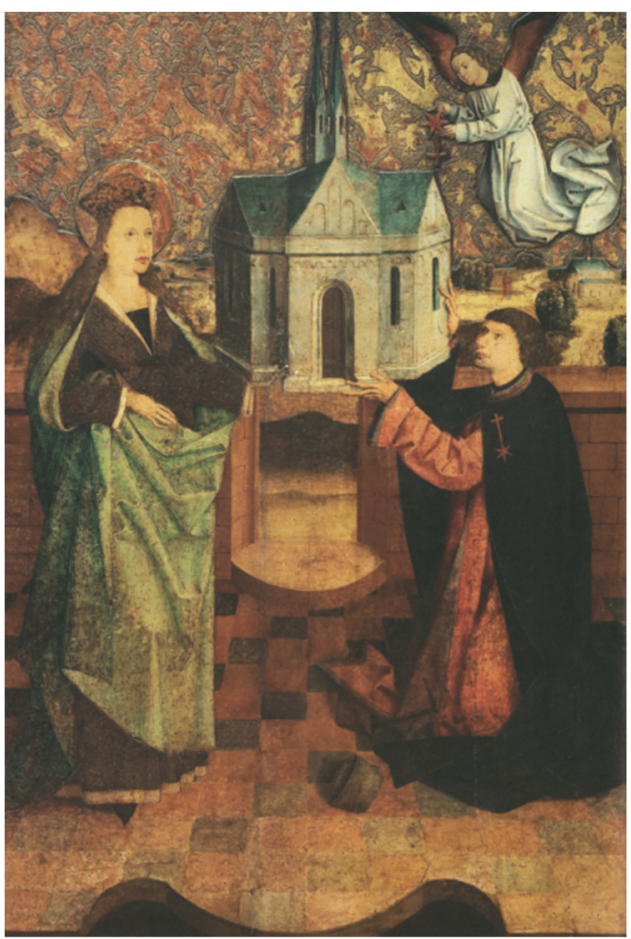

Figure 2. Saint Agnes of Bohemia Gives the Grandmaster a Model of the Church. Located in Saint Vitus Cathedral in the Prague Castle and downloaded from Wikimedia Commons. In the public domain and from a scan of a Catalog of Exhibition (2011), Altarpiece of Mikulas Puchner. Artist and photographer unknown.

\section{Contributors to Agnes' Sovereignty and Decision to Become a Nun}

There is clearly an epistemological problem when seeking to explain the motivating factors underlying a decision made by someone else, particularly exacerbated by the attempt to do so nearly eight centuries after the event. It is nonetheless reasonable to claim, with but some degree of caution, that Agnes' heuristic childhood and youth in religious communities impacted greatly on her refusal to become a queen and instead dedicate her life to the Franciscan movement in the Clarissan model.

During the time leading up to her commitment to a pious life, Agnes had been influenced by a number of individuals. Her early years with Hedwig and the Cistercian nuns in Silesia and with the Premonstratensian nuns in Doxony, while not only providing the young and impressionable Agnes an education, introduced her to a spiritual lifestyle that she fully embraced. Additionally, Agnes' family members, particularly her mother, Constance; her cousin, Elisabeth of Hungary (1207-1231); Elisabeth's mother and Agnes' aunt, Queen Gertrude of Merania; her much earlier ancestors, Saint Ludmila and Duke Bořivoj I, and several other relatives, served as role models by demonstrating ways in which royal funds could be used to subsidize churches and convents. Moreover, in addition to providing financial support, many of her relatives entered convents, some as sisters, some as abbesses, and others simply to reside within the communities without taking vows. Agnes' mother was highly pious and a major donor to churches and nunneries, as well the founder of several hospitals. Following Otakar I's death in 1230, Constance founded the Cistercian abbey near Tišnov, Porta coeli Convent, in 1232/3, where she retired as a nun, living there until her death in 1240.

Agnes' cousin Elisabeth, whom Agnes emulated in many respects, was the daughter of Andreas II (c. 1177-1221), King of Hungary and Croatia and the brother of Agnes' mother Constance, and Queen Gertrude of Merania. Born in Pozsony, Hungary, when only four years of age Elisabeth was betrothed to Hermann (1202-1216), the oldest son of Landgrave Hermann I of Thuringia (c. 1185-1217) and taken to the family court of 
Thuringia in central Germany ${ }^{4}$. After five years Elisabeth's future husband died, at which time she was affianced to Hermann's younger brother, who as Ludwig IV (1200-1227) ascended the throne and wedded Elisabeth at Wartburg Castle in 1221. From all accounts this was a happy marriage, and the union led to the birth of three children. Called to the Diet in Cremona in 1226, Ludwig IV agreed to join Emperor Frederick II on the Sixth Crusade, but tragically he died from the plague in 1227, leaving Elisabeth a young widow living with relatives who did not approve of her religious leanings and expenditure of royal funds in assisting the poverty-stricken and infirmed.

Earlier, Elisabeth had become supportive of the Franciscan ideology learned from followers of Saint Francis who had made their way to Germany in 1223 seeking converts for the newly established Order. After Ludwig IV's death and suffering persecution by his family, particularly his mother and a brother-in-law, Elisabeth joined the Third Order of Saint Francis in 1228, remaining committed to aid the sick and impoverished. Initially founding a twenty-eight-bed hospital for the poor in Eisenach, she then moved to Marburg and spent her residual funds to build another hospital to care for patients suffering from leprosy, the disease caused by Mycobacterium leprae, that had spread across Europe in the thirteenth-fourteenth centuries. In this setting, the Hospital of Saint Francis, Elisabeth dedicated herself to caring for lepers until her early death.

Unfortunately for Elisabeth, she was treated harshly by Conrad of Marburg (c. 1180-1233), her confessor and a fanatical ascetic. Conrad was a priest, nobleman, and the first German Inquisitor, who was appointed by Pope Innocent III (1161-1216, papacy 1198-1216) and continued by Pope Gregory IX. Making heavy demands in terms of devotion and fasting, Elisabeth suffered beatings from Conrad ${ }^{5}$ when she failed to meet his unrealistic expectations. Such treatment, along with that of her husband's relatives, undoubtedly contributed to her death in 1231 at just twenty-four years of age. Complementing her charitable life, a number of miracles were attributed to Elisabeth, who was canonized by Pope Gregory IX in 1235. A number of sources discussing Elisabeth are available for further reading (Barratt 1991; Mueller 2006, pp. 54-55; Aaij 2007; Wolf 2010; Burke 2016).

Although never meeting in person, the contemporary Francis of Assisi (1181-1226) was another highly influential individual in Agnes' life. The son of a prosperous silk merchant, Francis renounced his patrimony and devoted his life to preaching in which he advocated the importance of living in total poverty and aiding the poor. Responding favorably to the teachings of Francis, Innocent III approved the first Rule submitted in $1209^{6}$, believed to be little more than some passages of the Gospel, possibly from Matthew and Luke, and the vows honoring poverty, obedience, and chastity. This approval, however, sufficed to found the Franciscan Order, although other Rules with expanded text were later accepted by Honorius III in 1221 and 1223, including in the latter the fundamental Rule of the Order dictating the lifestyle of the brothers of the Friars Minors: ' ... to observe the holy Gospel of our Lord Jesus Christ by living in obedience, without property and in chastity.' While the wording differs slightly depending upon the translation, the intent and meaning of the Rule remains clear. Much has been written on the life of Francis (cf. Robson 1997; Wolf 2003; Le Goff 2004).

Another contemporary was Clare of Assisi (1194-1253), with whom Agnes corresponded but never met. Additionally, from a prosperous family, Clare was deeply moved upon hearing the sermons and teachings of Francis in San Rufino in 1211. Meeting Francis in 1212 at Santa Maria degli Angeli, Clare renounced her social status to devote her life to poverty and to caring for the sick and indigent. In the same year, along with Francis, Clare founded the Second Order of the Poor Ladies, the Poor Clares, and joined Francis and his followers at the Portiuncula, about four kilometers from Assisi, before being transferred to the Benedictine convents of Bastia and then Sant' Angelo di Panzo. Her last move was instigated by Francis who had rebuilt the church of San Damiano and adjacent convent in Assisi. Clare became abbess of the abbey in 1216 and in 1255 was canonized by Pope Alexander IV (late twelfth century-1261, papacy 1254-1261). 
Clare was highly supportive of the younger Agnes and served as a distant mentor and advisor as Agnes navigated the path to join the Second Order of the Poor Ladies in 1234. At times Clare's correspondence took the form of a spiritual mother writing to her daughter, the penultimate paragraph of her last letter being as follows. 'Farewell dearest daughter, together with your own daughters, until we meet at the throne of glory of the great God, and pray for us.' (Monagle 2015).

Unfortunately, although the letters of Agnes are no longer extant, the writings of Clare to Agnes are available and have been extensively studied and contextually analyzed (Van den Goorbergh and Zweerman 2000; Mueller 2003, 2010; Hahn 2014; Monagle 2015). Like much of Middle Age correspondence, the letters are rhetorically and metaphorically expressive. Interestingly, in several instances Clare paraphrased from The Legend of S. Agnes of Rome (Fleming 2010) in her letters to Agnes (Mueller 2010, pp. 169-98). Many additional sources are available describing the life of Saint Clare (cf. Mueller 2006; Pattenden 2008; Debby 2014; Hahn 2014).

\section{Expending a Royal Dowry and Becoming a Resolute Abbess}

In the early 1230s on land donated by her brother King Wenceslaus I, a site known as Na Františku along the banks of the Vitava River in Prague, Agnes used her royal dowry to begin the first phase of construction of a complex consisting of a hospital for the poor, begun in 1233 and dedicated to Francis; a convent for Poor Clares (Figure 3); the Church of Saint Francis, consecrated in 1234; and later a monastery for brothers who would attend patients and administer the hospital, this being located in a portion of the former hospital space. The complex was the first Gothic building in Prague (see Figure 4 for a contemporary view of the Saint Agnes Convent). Thus, Agnes was responsible for the first Clarissan house and the first double cloister north of the Alps (Felskau 2017).

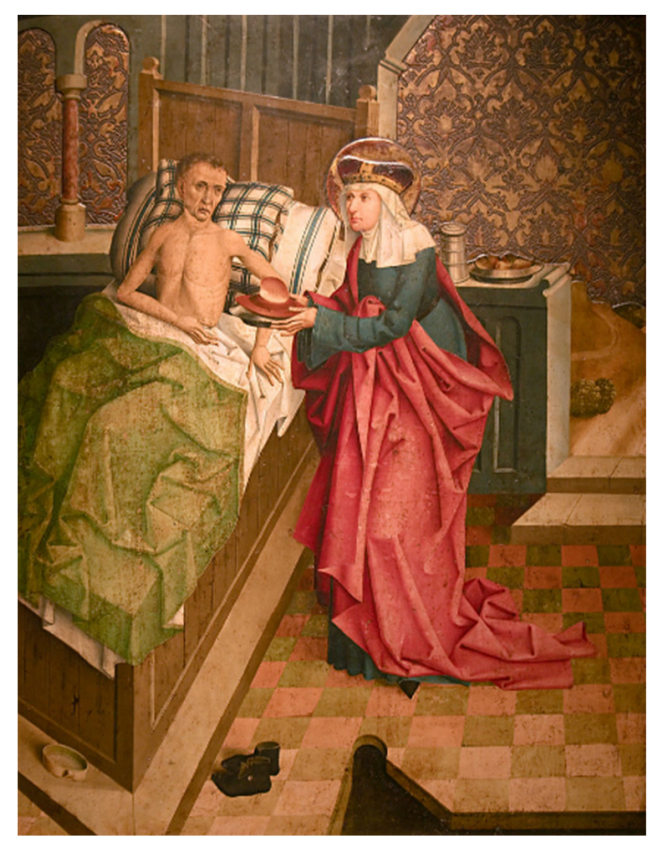

Figure 3. Agnes Tending the Sick. Located in the National Gallery, Prague and painted by Bohemia Master of the Year 1482. Downloaded from Wikimedia Commons and in the public domain. Photograph by Adrian Siemieniak. 


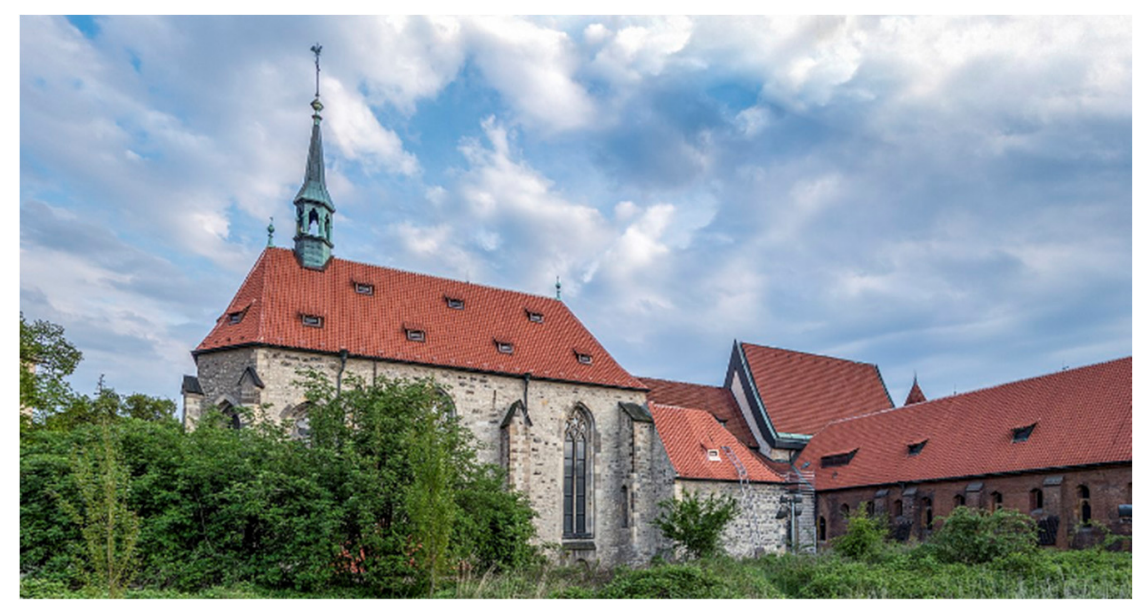

Figure 4. Convent of Saint Agnes of Bohemia. Licensed under Creative Commons Attribution, downloaded from Wikimedia Commons, and in the public domain. Photograph by Jerzy Strzelecki.

In addition to providing property, Wenceslaus I also gave royal support, thus relieving the complex of all taxation on the buildings and land. In strong backing of Agnes, her mother Queen Constance gave estates to ensure the hospital's sustainability. Wenceslaus I and another brother, Prěmysl (1209-1239), Margrave of Moravia, also donated an estate to enhance the financial security of the hospital. Agnes, having committed herself to live a life of poverty with no possessions, generously bequeathed the endowments to the hospital and specified that the combined income could not be used in any context for support of the convent. Instead, the sisters would depend upon the citizens of Prague and the Franciscan brothers for their needs. Further construction continued through the 1260s, including the addition of a kitchen and culminating in the Church of the Holy Savior, which would also serve as a mausoleum for the royal family.

Arriving in Prague in c. 1232, brothers of the Friars Minor identified a number of pious lay brothers, the Crusaders of the Red Star (Rüther 1999), who were commissioned by Agnes to staff the hospital and administer support from the endowment. Having heard of Agnes' commitment to the teachings of Francis, Clare requested in 1233 that Gregory IX allow five nuns from Trent to relocate to the fledgling priory, a request that Gregory approved. Shortly thereafter seven noble Bohemian women joined the original five nuns. On Pentecost Sunday, 1234, Agnes appeared in the newly constructed convent of Poor Clares in her finest clothing, which she proceeded to remove, revealing the coarse habit she would wear the remainder of her life; moreover, her renunciation of a secular life was accompanied by the cutting of her lovely long hair, an event witnessed by her sister Anna (Klaniczay 2002, pp. 238-41). Entering the convent as abbess, Agnes remained there throughout her life.

The complex erected by Agnes serves as testament to her unwavering commitment to the teachings of Saint Francis, as well as the tenaciousness and fortitude of this thirteenth century woman, born into royalty, to use hers and her family's influence and financial resources to further the teachings of the nascent Franciscan movement. To Agnes, sharing the same commitment as did Clare, poverty and a life without endowment was an essential element of her religion that was required to attain coalescence with Christ. In recognition of her northern sister's profound steadfastness and dedication, Clare wrote her first letter to Agnes in 1234 commending Agnes for choosing a life of poverty as proscribed by Francis ${ }^{7}$.

Pope Gregory IX, while supporting the Franciscan movement, was concerned about the number of convents that were emerging with the concomitant increase in the number of Franciscan nuns living in abject poverty. The image of destitute women of the Church begging for food or depending upon brothers to feed them was abhorrent to him. Moreover, he was also concerned that in time the papacy would be under pressure to support them. In short, he was desirous that the sisters have some form of financial support, and in Prague 
the solution seemed obvious since ample funds were available. In 1235 Gregory IX wrote Agnes and unequivocally decreed that the generous endowments of the hospital would also be available for the support of the convent ${ }^{8}$, thus undermining Agnes' desire that the convent not be subsidized.

Seeking advice from Clare, as is apparent from Clare's second letter to Agnes, she was advised in no uncertain terms to disregard the pope's command ${ }^{9}$. Further, Clare suggested that Agnes seek support from Brother Elias (c. 1180-1253), who in 1232, following the death of Francis, had been elected the Minister General of the Order of Friars Minor. Taking her recommendation, Agnes approached Elias and also her brother King Wenceslaus I, both of whom agreed to intervene on her behalf, writing to Gregory IX in 1237 (Mueller and Felsk 2011, p. 141). Not wishing to offend Wenceslaus I and needing his support to buffer the aggressiveness of Frederick II, Gregory IX was also influenced by the support offered by Brother Elias. He notified Agnes by letter in 1237 negating his previous stand and accepted that the convent would not be required to share the endowments of the hospital. While making this concession, however, Gregory IX placed the convent under the Rule of Saint Benedict, rather than the Franciscan Rule.

In a separate letter to the hospital master, Gregory IX recognized the Order of the Crosiers of the Red Star, the first religious order originating in Bohemia. The brothers were to observe the Rule of Saint Augustine and practice charitable works. Further, Gregory IX granted the medical facility to these Augustinian monks as they, unlike the Franciscans, could accept and continue to receive the assets required to maintain and meet operational costs. He also assigned the local Dominican province as visitators to the hospital, thus involving several Orders of the Church within this complex. In 1238 Gregory IX conceded the 'privilege of poverty' to the convent, although qualifying this by saying that the nunnery could receive support, but such was not required.

Unhappy with Agnes' continued refusal to accept independent financial support for the convent, Gregory IX hoped to entice the nuns living in the convent to agree to use the generous endowments. As part of his inducement, he informed them that he was relaxing their dietary and fasting requirements. Agnes evidently sought Clare's advice again, as ascertained from Clare's third letter to Agnes in which she reminded her that the fasting requirements were voluntarily for each sister and admonished Agnes for her own overly strict $\operatorname{diet}^{10}$. It is doubtful that Agnes adhered to Clare's recommendation regarding fasting and, determined to maintain her convent's original mission, persisted in her request that the convent be placed under the Franciscan Rule. Refusing to grant this entreaty, Gregory IX admonished Agnes for failing to accept his decisions, particularly that of adhering to the Benedictine Rule.

Gregory IX's resolution was based on his insistence that the Ugolinian Rule be adopted. Before becoming Pope, Gregory IX, then Ugolino di Conti, was named Cardinal by Pope Innocent III in 1198. Knowing of Ugolino's strong support of women choosing a life of devotion within the Church, Innocent III's successor, Pope Honorius III, asked Ugolino to develop a uniform rule that would apply to all female religious Orders. He was also instructed to formulate a plan for implementing the decree of the Fourth Lateran Council of 1215 stipulating that new religious Orders were prohibited and that new adherents to a life of religion must do so in one of the existing Orders. As applied to nuns, Ugolino recommended that they be under the dominion of the Apostolic See and follow the Rule of Saint Benedict (Mueller 2006, p. 19). Following this Ugolinian Rule, Gregory IX felt thoroughly justified in his exhortation that Agnes and the nuns in the Prague convent follow the Rule of Saint Benedict and not the Rule of Saint Francis, which he believed too restrictive for women. In further correspondence with Clare and then the Pope, Agnes was able to obtain Gregory IX's permission for her convent to have fasting regulations consistent with those of the convent of Saint Damiano. Gregory IX would not, however, offer Agnes the Rule of Saint Francis that she so ardently desired.

Realizing Gregory IX's inflexibility in this matter, Agnes decided to wait and begin negotiations with his successor. Following Gregory IX's death in 1241, the newly elected 
pope, Celestine IV (birthdate unknown, death in 1241), served in office only three weeks before dying himself. His successor was Innocent IV (1195-1254, papacy 1243-1254) whom Agnes approached in 1243 requesting recognition of the sisters as Franciscan. In responding, Innocent IV refers to Agnes as a 'sister of the Order of Saint Damian,' however, he supported Gregory IX's decision that Agnes' convent must follow the Rule of Saint Benedict.

Additional correspondence transpired between Agnes, Clare, and Innocent IV. In summary, the pope accepted Agnes' and Clare's desire that, upon their discretion, Franciscan brothers could enter the convents and attend the spiritual needs of the sisters, but he refused to capitulate and place them under the Rule of Saint Francis. Ever persistent and fully committed to her goals, Agnes engaged in further communications with the Pope. In 1247, Innocent IV finally yielded and proclaimed that the sisters were to be under the Order of Friars Minor of their region and, moreover, that the Rule of Blessed Francis replace that of the Rule of Blessed Benedict. On the other hand, he introduced the caveat that the convent could have financial support and own possessions. It was a partial victory for Agnes, but it firmly established her position as a powerful voice in the Church, able to push for theological, ecclesiastical, and political matters (Klaniczay 2016, pp. 130-31). Regardless of the Pope's decision, she was committed to adhere to the principle for which she had so valiantly struggled, namely that the convent have no endowment.

In time, as Clare was nearing death, with the support of Cardinal Rainaldo dei Conti di Segni (papacy as Alexander IV) she wrote what came to be known as the Rule of Saint Clare outlining her perspective on the 'privilege of poverty' and its intent to the sisters of San Damiano (Mueller 2000, p. 284) ${ }^{11}$. This Rule was approved by Innocent IV in 1253, and it is believed that Clare sent a copy to Agnes who was also able to achieve its acceptance by Alexander IV for the convent in Prague ${ }^{12}$. In her last letter to Agnes, written in 1253 as Clare lay dying, she gave lavish praise to Agnes as her spiritual daughter ${ }^{13}$.

In 1279 and 1280, the depredations of wars, rebellions, epidemics, famine, and floods led to severe starvation and disease that were ravaging the citizens of Prague, including the sisters of the Convent who were suffering badly as well. Anarchy was setting in with royal holdings being taken. Consuming even less food then normal in order to provide more nourishment for the other sisters, Agnes' health deteriorated, and her physical condition was very poor when she passed away in 1282 . Her body, placed behind the grating of the sister's chapel, lay in state for two weeks, during which period many of Prague's poor came to pay their final respects. After a life of prayer and service, Agnes was buried in her beloved convent.

Following in the path of two women contemporaries who had greatly influenced her, Saint Elisabeth of Hungary and Saint Clare of Assisi, Agnes was unwavering in her vision for her destiny, and her accomplishments in thirteenth-century Prague and environs were many. She served as a role model to other daughters of royalty, including her sister Anna, who was also influenced by her cousin Elisabeth and her mother-in-law Hedwig, the latter of whom she honored with the construction of a church ${ }^{14}$.

Over the years this long-lasting royal lineage had generously supported the Church financially and provided numerous sisters to various Orders. Living over seven decades, Agnes witnessed four of her relatives as Bohemian kings, her father, Otakar I; her brother, Wenceslaus I; her nephew, Otakar II; and her grandnephew, Wenceslaus II. For an overview of the political events occurring between 1248-1306 involving the House of Prremsyl, the reader is referred to the Appendix A for a summary of the kingships of Wenceslaus I, Otakar II, Wenceslaus II, and Wenceslaus III. The death of Agnes in 1282 preceded by just over two decades the inglorious ending of the Prremyslid Dynasty when her great-grandnephew, Wenceslaus III, was stabbed to death by an unknown assassin in 1306.

Centuries after her death, the Church accepted that Agnes exhibited resolute Christian values and was blessed with the gift of miracles, including her purported healing abilities and visions. She was beatified in 1874 by Pope Pius IX (1792-1878, papacy 1846-1878) and canonized in 1989 by Pope John Paul II (1920-2005, papacy 1978-2005). For a description of the early canonization efforts on behalf of Agnes, the reader is referred to Felskau 
(2017, pp. 130-43). Several excellent hagiographies on the remarkable life of Agnes are recommended for the interested reader (Mueller 2000; Mueller 2006, pp. 53-56; Seton 2010; Mueller and Felsk 2011; Felskau 2017).

\section{The Post-Agnes Era}

Lady Kunigunde of Bohemia (1265-1321), the daughter of Otakar II and his second wife, Queen Kunigunda of Slavonia/Halych, joined the Order of Poor Clares and entered Agnes's Convent in 1276, becoming the new abbess upon Agnes' death. However, in 1291, Kunigunde's brother, Wenceslaus II, ordered a marriage with Boleslaus II of Masovia (c. 1253/58-1313), forcing her to leave the convent. The union produced two children and lasted until 1302 when Boleslaus II divorced Kunigunde, at which time she returned to Prague and joined the Benedictine Convent of Saint George, Prague castle, where she served as abbess until her death. As a book collector and patron of the arts, Kunigunde, like her great-aunt Agnes and later Anne of Bohemia (1366-1394), Queen of England and the first wife of King Richard II (1367-1400), made significant contributions to medieval Bohemian literature, an unusual role for most women of the period (Thomas 1998, p. 15).

With the number of sisters gradually declining over the ensuing years, the nuns moved out of the convent in 1419/20 at the outbreak of the Hussite Wars as their spiritual haven was redirected to the war effort. Before leaving, however, they exhumed Agnes' remains and placed them in a wooden coffin that was buried at an undisclosed location for protection.

Later, Dominican sisters occupied the convent, but in the seventeenth century the Franciscan sisters returned, remaining there until the late eighteenth century when the building was sold under the reign of the Holy Roman Emperor Joseph II (1741-1790), who was abolishing numerous churches, monasteries, and convents. The new owners rented space for workshops, storage facilities, and small apartments for the poor. The hospital and monastery housing the friars were eventually demolished ${ }^{15}$ as a neighborhood developed in the vicinity of the convent and churches (Figure 5).

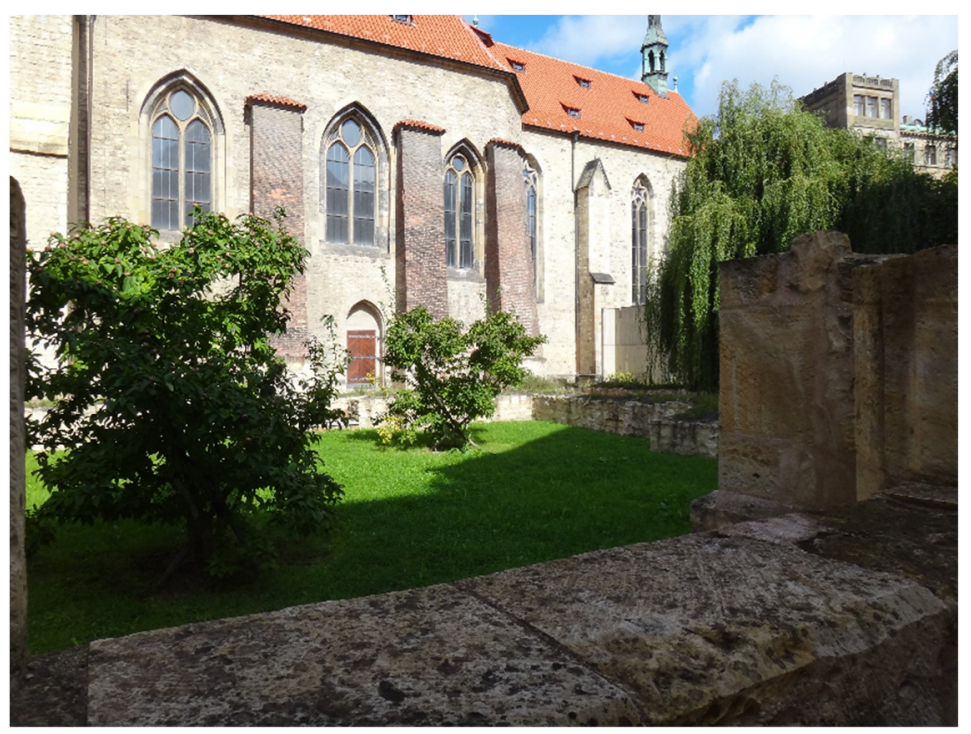

Figure 5. Convent of Saint Agnes viewed from the site of the former monastery. The foundations are visible in the lower front of the picture, and the view is looking toward the Church and the Chancel of Saint Francis (to the left) and the Church of the Holy Savior (to the right). The former hospital, no longer extant in this location, would have been toward the right quadrant of the photograph where the large tree is now standing, and from there extending beyond into what is now a neighborhood. Photograph by the author. 
Realizing the architectural and historical importance of the convent, chapels, and the Churches of Saint Francis and of the Holy Savior, renovation was begun in the nineteenth century. Yet, it was not until the twentieth century that the refurbished edifice visible today was completed, and in 1963 the convent was placed under the sponsorship of the National Gallery of Prague. It presently continues as a contemplative and meditative space through the use of religious art.

\section{The Enduring Legacy of the Saint Agnes Convent}

Today the interior Gothic rooms and hallways (Figure 6) form a glorious setting for the splendid collection of over two-hundred works of Medieval and Renaissance art of Prague and Central Europe from the thirteenth through the sixteenth centuries. Excellent examples of religious art created during Czech's Golden Age are on view in these galleries, as are some earlier and later works.

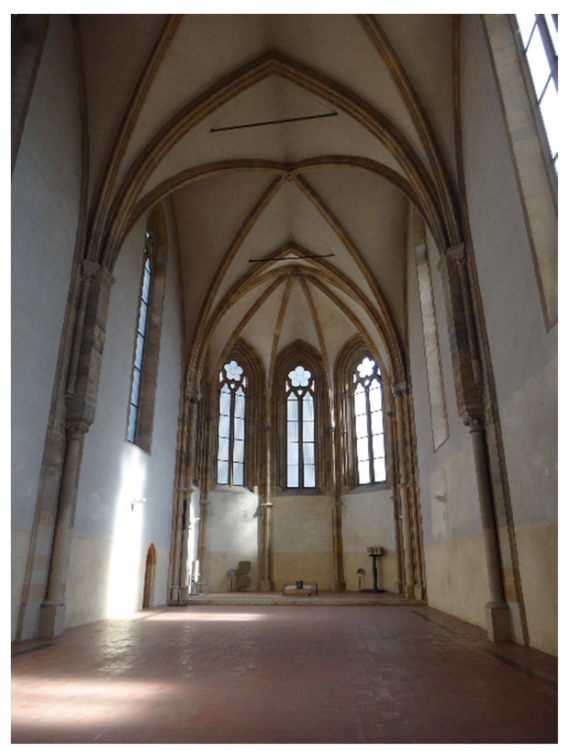

Figure 6. Internal view of the Saint Agnes Convent showing Gothic arches in one of the hallways. Photograph by the author.

Paintings by three of the leading fourteenth-century artists working in and around Prague adorn the walls and are discussed herein. Included in this group are: (a) Master Theodoric of Prague (c. 1328-1381) and two anonymous artists and their workshops referred to as (b) the Master of Vyšší Brod (also denoted as the Master of the Hohenfurth Cycle), whose better-known paintings were done in about 1345-1350, and (c) the Master of the Třeboň Altarpiece, paintings that were completed in about 1380-1390.

Master Theodoric of Prague (c. 1328-1381) was commissioned by Charles IV (1316-1378), Holy Roman Emperor and King of Bohemia, to execute one hundred and thirty panel paintings and frescoes of saints, prophets, patriarchs, angels, church officials, and popes for the Chapel of the Holy Cross in the Karlštejn castle. These works, most of which have survived, were done by the Master and his assistants between about 1360-1365 and have been discussed and analyzed in depth by Friedl (1956) and Frinta (Frinta 1975-1976). Considered one of the originators of the 'Soft Style', several of Master Theodoric's paintings are shown in Figures 7-10. It is believed that Master Theodoric visited Venice, where he was influenced by much of the Byzantine art he admired, particularly that in the Basilica of Saint Mark. Indeed, his use of pastiglia or relief decoration to cover backgrounds and frames, as well as his use of silver coverings or hammered gold of icons, reflects a Byzantine effect. As apparent in the figures below, his paintings are bold, offer three-dimensionality, and demonstrate a most effective use of light. The figures fill the frames, giving them an 
oversize monumentality. The convergence of these effects is readily appreciated in Master Theodoric's paintings of Saint Jerome (Figure 7) and Saint Gregory (Figure 10).

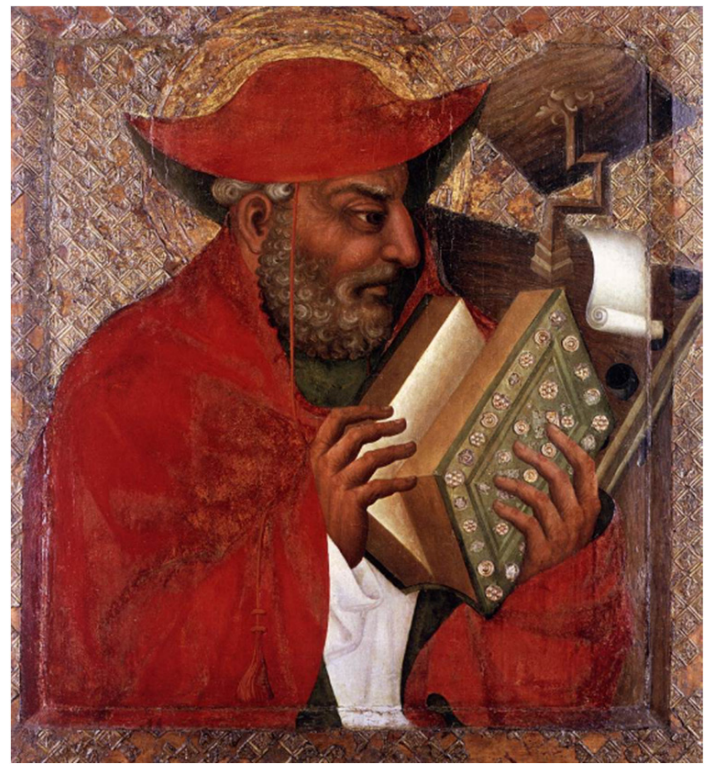

Figure 7. Painting of Saint Jerome by Master Theodoric of Prague. Downloaded from Wikimedia Commons and in the public domain. Photographer unknown.

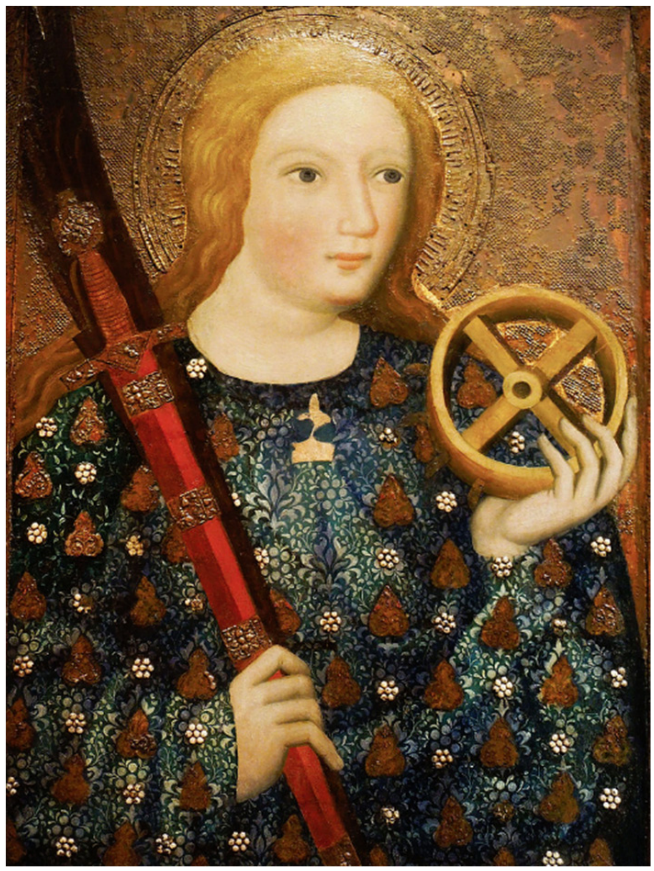

Figure 8. Painting of Saint Catherine by Master Theodoric of Prague. Downloaded from Wikimedia Commons (in Creative Commons) Attr. Bation-Share, Alike 4.0 International license. Photographer unknown. 


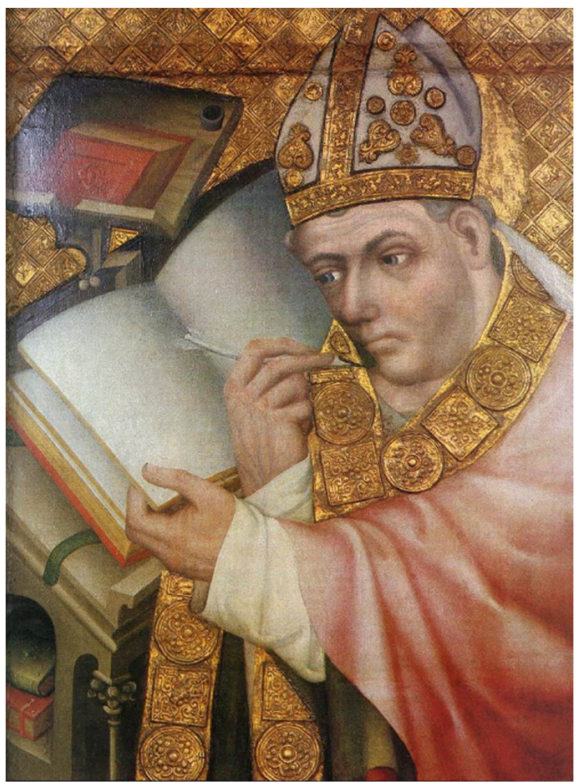

Figure 9. Painting of a Saint by Master Theodoric of Prague. Downloaded from Wikimedia Commons, Web Gallery of Art, Public Domain. Photographer unknown.

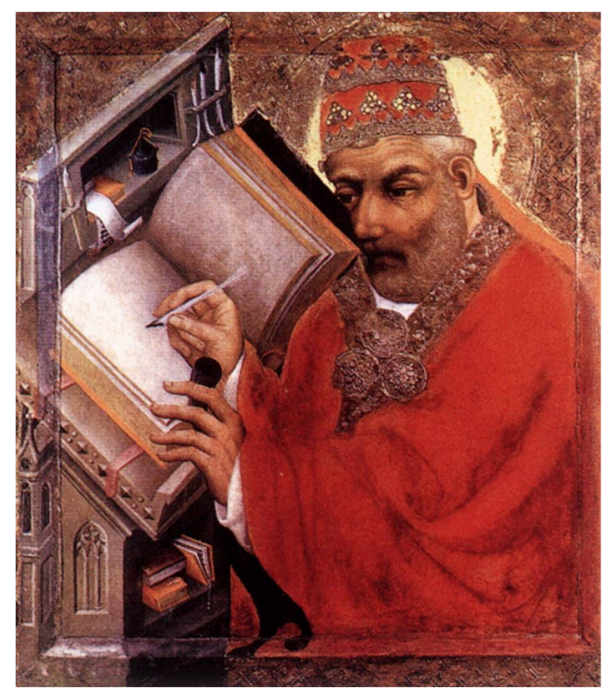

Figure 10. Painting of Saint Gregory by Master Theodoric of Prague. Downloaded from Wikimedia Commons, Public Domain. Photographer unknown.

The Master of Vyšší Brod derives its name from the nine panel paintings done in about 1345-1350 for the Cistercian Abbey of Vyšší Brod that depict scenes from the life of Christ. Peter I of Rosenberg (d. 1347) was a patron of the monastery who commissioned the paintings (Gersdorfova 2015). Figure 11 shows one of the panels, Virgin Mary Teaching the Apostles (also known as Descent of the Holy Spirit) in which the Virgin Mary, holding a book, is surrounded by the twelve apostles who are, from the descent of the Holy Spirit, to learn communication in all languages in order to spread the gospel. A form of the Byzantine painting tradition was employed by the use of layers, while the apostle holding a finger to his mouth, denoting obedience, reflects an Italian influence. The net result was, without question, Central European in nature. The use of brilliant and bold colors, the individuality of the figures, and a hint of perspective, renders this a magnificent work of art. 


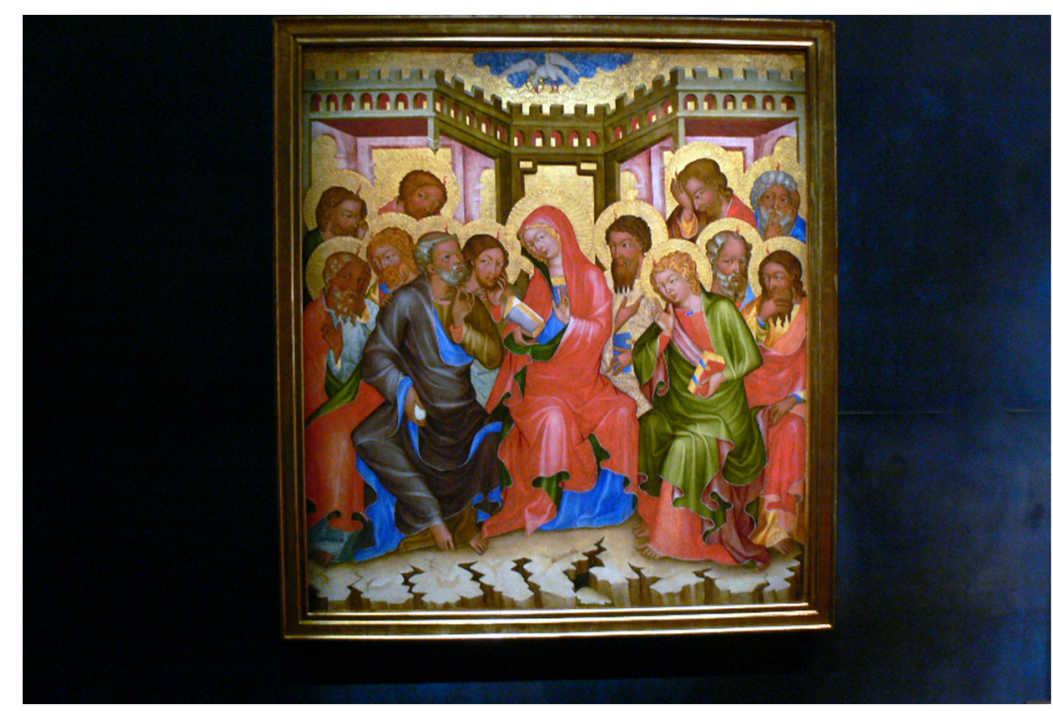

Figure 11. Painting of Virgin Mary Teaching the Apostles by the Master of Vyšší Brod (anonymous artist). Downloaded from Wikimedia Commons and made available under the GNU Free Documentation license. Photograph by Wolfgang Sauber.

Another highly accomplished anonymous artist of the period was the Master of the Třeboň Altarpiece whose major work was done between about 1380-1390 (Royt 2015). Commissioned by Archbishop Jan of Jenstejn for the Augustinian Church of Saint Giles in Třeboň, the remaining altarpiece consists of three wings, painted on both sides, depicting Christ on the Mount of Olives, The Tomb of Christ, and the Resurrection. Figure 12 shows a painting of Saint James, Saint Bartholomew, and Saint Phillip, located on the reverse side of the Resurrection, and Figure 13 depicts Saint Giles, Saint Augustine, and Saint Jerome, painted on the reverse side of the Entombment. Credited with creating what became known as the 'Beautiful Style', the artist used chiaroscuro in some of his works, and the bold use of colors and light, with some semblance of three-dimensionality, adds to the quality of these paintings.

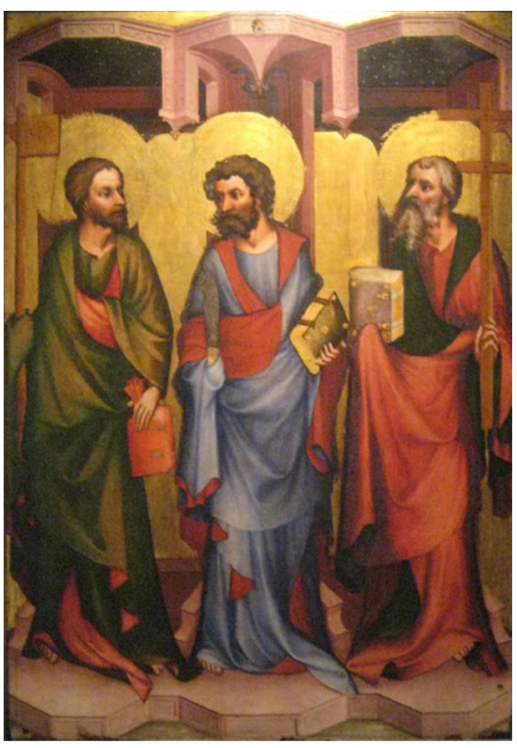

Figure 12. Painting of Saint James, Saint Bartholomew, and Saint Philip by the Master of the Třeboň Altarpiece. Downloaded from Wikimedia Commons and in the public domain. Photograph by Claire $\mathrm{H}$. 


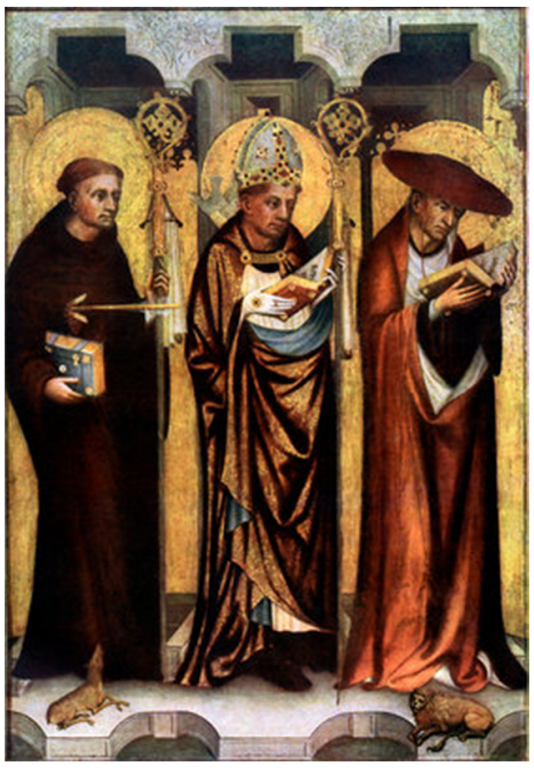

Figure 13. Painting of Saint Giles, Saint Augustine, and Saint Jerome by the Master of the Třeboň Altarpiece. Downloaded from Wikimedia Commons and in the public domain. Photograph by Magnolia Box.

A brief discussion on the technical aspects of these early artists is in order. The magisterial paintings discussed were executed on canvas attached to wooden boards made of sycamore, linden, beech, or spruce. The paintings of Master Theodoric have been studied in detail and can be briefly summarized. Two layers of priming formed the ground, the lower one being a siliceous layer bound with glue, starch, and oil and the upper one composed of chalk, which contains cocolites or fossil shells. Preparatory drawings were made with bold black brush strokes and often reflected the work of one or more artists. This was followed by a layer of oil-based lead white that serves to reflect diffuse light striking it through the added translucent layers of tempera and oil. A wide variety of pigments were used to achieve the desired colors in the paintings (Hradil et al. 2020). Lastly, relief decorations were applied to the frame and background (cf. Hamsík 1992 for a succinct overview). Analytical studies of the pigments used by the Master of Vyšší Brod in the green cloak in Figure 11 demonstrated that a lead-tin $(\mathrm{Pb}-\mathrm{Sn})$ yellow was Type II $\left(\mathrm{PbSnO}_{3}\right)$ mixed with yellow ochre (hydrated iron oxide), lead white, and copper green pigment (Šefcu et al. 2015). Another investigation showed that the blue in the robes was from a high-quality lapis lazuli backed by a white imprimatur that was executed in lead (Šefců et al. 2016). In contrast to the use of a type II lead-tin yellow, another painting from the Master of Vyšší Brod was found to contain Pb-Sn Type I (Hradil et al. 2007). To be determined is whether these two paintings were executed by the Master or by another artist in the workshop.

The fourteenth-century artwork in Prague and environs, with its vivid colors and striking compositions, parallels that being produced by the Florentine artist, Giotto (c. 12671337), whose works in the late thirteenth century and early fourteenth century can be found in Assisi (San Francesco), Florence (Santa Croce, Santa Maria Novella, and the Uffizi), and Padua (Arena Chapel), when a hint of perspective was being introduced a number of years before Brunelleschi (1377-1446) and Masaccio (1401-1428) added accurate mathematically based depth to two-dimensional compositions, defining a new era in Florentine painting (Puett and Puett 2016, pp. 80-104).

\section{Conclusions}

In closing, suffice it to say that Agnes was in the central European avant-garde of a small number of women who, centuries before women's rights and education were recognized, contributed significantly to religious goals, societal needs, literature, and arts. 
She was strongly influenced and motivated by family members and non-related religious contemporaries to forego her expected role and, rather, dedicate herself to the teachings and lifestyle championed by Saint Francis and Saint Clare. Tenacious in meetings her objectives, she chose her own path in the Franciscan model. Agnes showed, along with others, that a powerful father, kings, and popes could be confronted and overruled, and that dowries could be used to benefit the glory of God. Agnes' firm resolve to lead a life dedicated to poverty and without endowment for her convent, while providing Prague a hospital for the poor, a convent for sisters, a monastery for brothers, a church, and a royal mausoleum, assured her of recognition as a major contributor to the Franciscan movement, particularly that of the Poor Clares, in thirteenth-century Prague. Although the hospital and monastery were eventually demolished, the convent was sold to house the poor and create workshops, thus preserving it until its architectural importance was recognized in the twentieth century when it was repurposed as a museum for a Medieval and Renaissance religious art collection. All works of art in the Saint Agnes Convent, including both paintings and statuary in such a glorious and historical setting, invite thoughtful contemplation, thus speaking to the appropriateness of transforming this original convent, founded to foster spiritual meditation, into a museum that enriches the viewer and can once more render ecclesiastical reflection. Whereas the functions of the original structures have changed, in an interesting twist of irony, the convent, originally built to seclude the sisters, now welcomes all comers to enjoy the premiere art collection. Agnes' legacy remains strong and intact.

Funding: This research received no external funding.

Institutional Review Board Statement: Not applicable.

Informed Consent Statement: Not applicable.

Data Availability Statement: Not applicable.

Acknowledgments: I thank Susan Brunn Puett for her many invaluable suggestions and comments.

Conflicts of Interest: The author declares no conflict of interest.

\section{Appendix A. Overview of the House of Přemsyl 1248-1306}

In 1248, Agnes' nephew, Otakar II (c. 1233-1278), son of Wenceslaus I and Kunigunde of Swabia (1202-1248), led a rebellion against his father and declared himself King of Bohemia. Wenceslaus I, however, defeated his son and then imprisoned him. In time they reconciled and Wenceslaus I proclaimed his son as Margrave of Austria. Agnes was instrumental in mediating this peace negotiation, which occurred in her convent (Klaniczay 2002 , p. 278). Following Wenceslaus I's death in 1253, Otakar II replaced him and served as king from 1253-1278. Otakar II's first marriage was to Margaret of Austria (1204-1266) who, being twenty-six years his senior, failed to produce children, leading to an annulment of the union. He then married Kunigunda of Slavonia/Halych (1245-1285) who bore the couple three children that survived infancy. The one legitimate son was Wenceslaus II (1271-1305). In recognition of Otakar II's military prowess in achieving victories for the short-lived empire he was building, he became known as the Iron and Golden King.

Believing that he had the support of Pope Gregory X (c. 1210-1276, papacy 1271-1276) for his anticipated appointment to the imperial throne of Germany, Otakar II was infuriated when Gregory instead backed Rudolf I of Habsburg (1218-1291), Count of Habsburg from c. 1240 and King of Germany 1273-1291. The new emperor forced Otakar II to relinquish many of the lands he had conquered and retain only Bohemia and Moravia. Refusing to recognize Rudolf I as King of Germany, Otakar II raised an army, composed of his own Bavarian troops allied with many from Brandenburg, Poland, and Bavaria, to fight him. Rudolf I, in turn, enlisted King Ladislaus IV of Hungary (1262-1290) and his soldiery to join in the upcoming engagement. In a large conflict that involved over fifteen thousand cavalrymen, the allied armies of Otokar II and Rudolf I met in the Battle on the Marchfeld 
at Dürnkrut and Jedenspeigen in 1278. Rudolf I was the victor, and Otakar II was killed on the battlefield. After Otakar II's death, his widow, Queen Kunigunda, began an affair with a Czech nobleman, Záviś of Falkenśtejn (1250-1290), whom she later married.

Upon his father's death, Wenceslaus II inherited the throne and served as King of Bohemia (1278-1305), King of Poland (1300-1305), and Duke of Cracow (1291-1305). However, being only seven years of age when the throne became his, he was incapable of effectively ruling for a number of years. During this period several regents oversaw the affairs of the kingdom. His cousin, Otto V, Margrave of Brandenburg (1246-1298), with whom he lived, served until 1283. Then, dowager Queen Kunigunda and Záviś of Falkenśtejn were regents until Wenceslaus II assumed control. Upon taking the crown, Wenceslaus II ordered that Záviś be arrested for high treason in 1289 and then had him executed in 1290. The territory of Bohemia was greatly expanded under Wenceslaus II, and the discovery of silver in central Bohemia near the end of the thirteenth century added immensely to the royal funds.

Following the death of Wenceslaus II in 1305, his son with Judith of Habsburg (1271-1297), Wenceslaus III (1289-1306), became King of Bohemia and King of Poland. Having served just one year on the throne, Wenceslaus III was assassinated in 1306.

\section{Notes}

1 Following this fratricide, Boleslaus I then served some thirty-five years as Duke of Bohemia, during which time he amassed a commendable record of territorial and economic development. Moreover, he was sympathetic to the growing acceptance of Christianity in Bohemia, perhaps attributable to the influence of his grandmother Ludmila.

2 The three kings of Germany conferring kingship to Otakar I were Philip of Swabia (1177-1208) in 1198, a member of the Hohenstaufen dynasty; the rival Otto IV of Brunswick (1175-1218) in 1203, a member of the Welf dynasty; and by Frederick II (1194-1250) in 1212, a member of the Hohenstaufen dynasty. Frederick II was an aggressive, powerful, cultured, and erudite ruler who, over the years, would also acquire the titles King of Sicily, King of Italy, King of Jerusalem, and Holy Roman Emperor. In recognition of Otakar I as one of the electors who supported his kingship, Frederick II issued the Golden Bull of Sicily in 1212 confirming Otakar I's title as king of Bohemia in 1212, as well as assuring hereditary rights to his offspring and granting autonomy to Bohemia.

3 Emigrating to Milan, Guglielma practiced a feminist Christianity and preached that the end of time was approaching. Moreover, upon resurrection she would return as the Holy Spirit incarnate to a religion led by women. Not tolerating such behavior, even after her death, the Church accused her of heresy, and her remains were exhumed and burned, with three of her followers dying at the stake. Tumultuous times these were.

4 When Elisabeth was in Thuringia and during an absence by her father, Elisabeth's mother was killed during a hunt by Hungarian nobles in 1213, who were displeased with Gertrude's dispensation of land grants and court positions to her German relatives.

5 Having a reputation for severe cruelty in his rout of heresy, Conrad was assassinated by knights while on a trip from Mainz to Marburg. Ironically, Agnes had saved Conrad's life in the late 1220s when he was in Bohemia inspiring nobles to join the Sixth Crusade. His efforts interfered with Otakar I's attempt to recruit the same group of men to join him in another war against Austria to avenge the duplicitous actions of Leopold VI. With his own plans for the Bohemian noblemen so undermined, an angered Otakar I ordered Conrad to be captured and beheaded. Just before the order was executed, Agnes escorted Conrad to a chapel to confess and receive communion. Afterwards, at Agnes' request, her father withdrew his death order of Conrad.

6 The timing of the 1209 approval by Innocent III was certainly auspicious for Francis, as it had been executed six years prior to the acceptance of canon 13 of the 1215 Fourth Council of the Lateran that prohibited the establishment of new religious Orders. Francis was canonized by Gregory IX in 1228.

7 '... Hearing the account, one that brings you the highest honor, of your holy conversion and manner of life, an account that has been reputably disseminated not only to me but to nearly every region of the world, I rejoice and exalt exceedingly in the Lord. ... I rejoice because you, more than others, could have enjoyed public ostentation, honors, and worldly status having had the opportunity to become, with eminent glory, legitimately married to the illustrious emperor, as would befit your and his pre-eminence. Spurning all these things with your whole heart and mind, you have chosen instead holiest poverty and physical want, accepting a nobler spouse, the Lord Jesus Christ, who will keep your virginity always immaculate and inviolate. ... ' (Mueller 2010, p. 261).

8 '... we have decided that the Hospital of Saint Francis situated next to your monastery, which you, daughter and abbess, built on land of the Roman church, is to be conceded to that monastery with its appurtenances forever. Also, we order that the same hospital with all its goods can not be separated from the monastery by any means or plans. Moreover, let the income of its possessions fall to the use of yourselves and those who succeed you and remain safe forever through the authority of the apostolic see. .. ' (Mueller 2000, p. 271).

9 '... Clare, useless and unworthy handmaid of the Poor Ladies, sends her greetings and the prayer that Agnes may always live in the utmost poverty. ... What you hold, continue to hold. What you do, keep doing and do not stop. But with swift pace, nimble step, and feet that do not 
stumble so that even your walking does not raise any dust, go forward tranquilly, joyfully, briskly, and cautiously along the path of happiness, trusting in no one and agreeing with no one insofar as he might want to dissuade you from pursuing your founding purpose or might place a stumbling block in your way, preventing you, in that perfection with which the Spirit of the Lord has called you, from fulfilling your vows to the Most High. ... Indeed, if someone tells you something else or suggests anything to you that may hinder your perfection or seems contrary to your divine vocation, even though you must respect him, still do not follow his advice. Instead, poor virgin, embrace the Poor Christ. ... (Mueller 2010, pp. 265-66)

10 '... I am filled with such great joy about your well-being, your happiness, and your favorable successes through which, I understand, you are thriving on the journey you have begun to obtain the reward of heaven. ... our most glorious father, Saint Francis, urged us to celebrate in a special way with different types of food. Indeed, your prudence knows that, with the exception of the weak and the sick, for whom he advised and authorized us to use every possible discretion with respect to any foods whatsoever, none of us who are healthy and strong ought to eat anything other than Lenten fare, on both ordinary days and feast days, fasting every day except on Sundays and on the lord's Nativity, when we ought to eat twice a day. And on Thursdays in Ordinary Time, fasting should reflect the personal decision of each sister, so that whoever might not wish to fast would not be obligated to do so. All the same, those of us who are healthy fast every day except Sundays and Christmas.... But because neither is our flesh the flesh of bronze, nor our strength the strength of stone, but instead, we are frail and prone to every bodily weakness, I am asking and begging in the Lord that you be restrained wisely and discreetly, dearest one, from the indiscreet and impossibly severe fasting that I know you have imposed upon yourself, so that living, you might profess the Lord, and might return to the Lord your reasonable worship and your sacrifice always seasoned with salt. ... ' (Mueller 2010, pp. 267-69).

11 '... that is, by not receiving or having possession or ownership either for themselves or through an intermediary, or even anything that might necessarily be called property, except as much land as necessity requires for the integrity and proper seclusion of the monastery, and this land may not be cultivated except as a garden for the needs of the sisters.' (Mueller 2000, p. 284)

12 Unfortunately, the documentation for this has not been located. Clare was able to achieve her lifelong desire for the convent.

13 '... I rejoice and exult for you in the joy of the Spirit, spouse of Christ, because like that other most holy virgin, Saint Agnes, you have been in an astonishing way espoused to the immaculate Lamb, who, having assumed responsibility for all the vanities of this world, takes away the sins of the world. ... Therefore, seeing this, O queen of the heavenly King, you must burn ever more strongly with the fervor of charity! ... . O blessed daughter, since my bodily tongue cannot in any way express more fully the love that I have for you, that which I have written is certainly inadequate. I beg you to receive these words with kindness and devotion, seeing in them at least the motherly affection, by which every day I am stirred by the fire of love for you and your daughters. ... ' (Mueller 2010, pp. 271-73).

14 Emulating her younger sister Agnes and cousin Elizsbeth, Anna established a hospital in Wrocław, dedicated to Elisabeth, and, like Agnes, arranged for its operation to be under the Crusaders of the Red Star. With the assistance of Agnes in negotiating with Pope Alexander IV, Anna also founded a convent for Poor Clares in 1257 in Breslau, where she spent her remaining years as abbess (Klaniczay 2002, p. 241).

15 Although the original Franciscan hospital no longer stands, modern Prague has an extant St. Francis Hospital, begun in the fourteenth century and built near the Church of Saint Simon and Juda, and sited close to the one built by Agnes. Following the tradition of Agnes, the newer hospital was founded as one to provide health care to the poor. It has been greatly enlarged over the centuries and currently is under the management of the city of Prague.

\section{References}

[N.B. Two additional definitive references on Saint Agnes that are not in English are: (a) Christian-Frederik Felskau. 2012. Agnes von Böhmen und die Klosteranlage der Klarissen und Franziskaner in Prag Leben und Institution, Legende und Verehrung, Nordhausen, Germany: Verlag T. Bautz GmbH (in German) and Helena Soukupová. 1989. Anežský klášter v Praze, Prague: Odeon (in Czech).]

Aaij, Michel. 2007. Saint Elisabeth of Thuringia, 1207-2007. The Heroic Age May, Issue no. 10. Available online: https://www. heroicage.org/issues/10/bio2.html (accessed on 3 August 2021).

Barratt, Alexandra. 1991. The Virgin and the Visionary in the Revelation of St. Elizabeth. Mystics Quarterly 17: 125-36.

Burke, Linda. 2016. A Sister in the World: Saint Elizabeth of Hungary in the Golden Legend. Hungarian Historical Review 5: 509-35.

Curta, Florin. 2019. New Powers (III): Přemyslid Bohemia. In Eastern Europe in the Middle Ages (500-1300). Leiden: Koninklijke Brill NV, chp. 19, pp. 389-408.

Debby, Nirit Ben-Aryeh. 2014. The Cult of St Clare of Assisi in Early Modern Italy. Surrey: Ashgate Publishing Limited.

Felskau, Christian-Frederik. 2017. Shaping the Sainthood of a Central European Clarissan Princess (1174-1243). In Les Saints et leur culte en Europe central au Moyen Åge (xie-début du xvie siècle). Edited by Marie-Madeleine de Cevins and Oliver Marin. Turnhout: Brepols Publishers, pp. 125-71.

Fleming, Julia, trans. 2010, The Legend of S. Agnes of Rome. In Appendix to Mueller, Joan. A Companion to Clare of Assisi. Leiden: Koninklijke Brill NV, pp. 199-208.

Friedl, Antonín. 1956. Master Theodoricus. Translated by I. R. Gottheiner. Prague: Artia.

Frinta, Mojmír S. 1975-1976. The Puzzling Raised Decorations in the Paintings of Master Theodoric. Simiolus: Netherlands Quarterly for the History of Art 8: 49-68. [CrossRef] 
Gersdorfova, Zlata. 2015. The Spiritual Environment and Artistic Heritage in South Bohemia of the 14th Century. Annales Universitatis Series Historica Special. In Monastic Life, Art, and Technology in the 11th-16th Centuries. Edited by Ileana Burnichioiu. Alba Iulia: Mega Publishing House, pp. 197-214.

Hahn, Michael. 2014. Clare of Assisi's Spiritual Teachings and Its Significance in Medieval Monasticism and in Modernity. Convocamus 1: $10-27$.

Hamsík, Mojmír. 1992. Master Theodoric's Painting Technique and Its Origin. Technologia Artis (Yearbook 2). Available online: https: / / technologiaartis.avucz/a_2malba-drevo-malir.html (accessed on 3 August 2021).

Hradil, David, Tomáš Grygar, Janka Hradilová, Petr Bezdička, Veronika Grûnwaldová, Igor Fogaš, and Miliani Costanza. 2007. Microanalytical Identification of Pb-Sb-Sn Yellow Pigment in Historical European Paintings and Its Differentiation from Lead Tin and Naples Yellows. Journal of Cultural Heritage 8: 377-86. [CrossRef]

Hradil, David, Janka Hradilová, and Bezdička. 2020. Clay Minerals in European Painting of the Medieval and Baroque Periods. Minerals 10: 255. [CrossRef]

Klaniczay, Gábor. 2002. Holy Rulers and Blessed Princesses. Translated by Éva Pálmai. Cambridge: Cambridge University Press.

Klaniczay, Gábor. 2016. The Power of the Saints and the Authority of the Popes. In Church and Belief in the Middle Ages. Edited by Kirsi Salonen and Sari Katajala-Peltomaa. Amsterdam: Amsterdam University Press B.V., pp. 117-40.

Le Goff, Jacques. 2004. Saint Francis of Assisi. Translated by Christine Rhone. London: Routledge.

Monagle, Clare. 2015. Poor Maternity: Clare of Assisi's Letters to Agnes of Prague. Women's Historical Review 24: 490-501. [CrossRef]

Mueller, Joan, and Christian-Frederik Felsk. 2011. A Dowry Given, Returned, and Given Again. Journal of Religion E Society Supplement 7: $134-49$.

Mueller, Joan. 2000. Agnes of Prague and the Juridical Implications of the Privilege of Poverty. Franciscan Studies 58: 261-87. [CrossRef]

Mueller, Joan. 2003. Clare of Assisi: The Letters to Agnes. Collegeville: Liturgical Press.

Mueller, Joan. 2006. The Privilege of Poverty: Clare of Assisi, Agnes of Prague, and the Struggle for a Franciscan Rule for Women. University Park: The Pennsylvania State University Press.

Mueller, Joan. 2010. A Companion to Clare of Assisi. Brill's Companions to the Christian Tradition. Leiden: Koninklijke Brill NV, vol. 21.

Pattenden, Miles. 2008. The Canonisation of Clare of Assisi and Early Franciscan History. Journal of Ecclesiastical History 59: 208-26. [CrossRef]

Puett, Susan B., and J. David Puett. 2016. Renaissance Art E Science @ Florence. Kirksville: Truman State University Press, University Park: The Pennsylvania State University Press.

Robson, Michael. 1997. St Francis of Assisi: The Legend and the Life. London: Continuim.

Royt, Jan. 2015. The Master of the Trebon Altarpiece. Prague: Karolinum Press. Distributed by the University of Chicago Press.

Rüther, Andreas. 1999. Between International Horizon and Regional Boundary: The Bohemian Crossiers of the Red Star in Silesia. In Mendicants, Military Orders, and Regionalism in Medieval Europe. Edited by Jürgen Sarnowsky. Hants: Ashgate Publishing Company, pp. 103-14.

Šefců, Radka, Štěpánka Chlumská, and Alena Hostašová. 2015. An Investigation of the Lead Tin Yellows Type I and II and Their Use in Bohemian Panel Paintings from the Gothic Period. Heritage Science 3: 16. [CrossRef]

Šefců, Radka, Václav Pitthard, Štěpánka Chlumská, and Ivana Turková. 2016. A Multianalytical Study of Oil Binding Media and Pigments on Bohemian Panel Paintings from the First Half of the 14th Century. Journal of Cultural Heritage 23: 77-86. [CrossRef]

Seton, Walter W. 2010. Some New Sources for the Life of Blessed Agnes of Bohemia: Including a Fourteenth Century Latin Version (Bamberg, Misc. Hist. 146, E.VII, 19) and a Fifteenth Century German Version (Berlin, Germ. Oct. 484). New York: Cambridge University Press. Aberdeen: The University Press. First published in 1915.

Thomas, Alfred. 1998. Anne's Bohemia, Czech Literature and Society, 1310-1420. Minneapolis: University of Minnesota Press.

Van den Goorbergh, Edith A., and Theodore H. Zweerman. 2000. Light Shining Through a Veil: On Saint Agnes of Prague. Translated by Aline Looman-Graaskamp, and Frances Teresa. Leuven: Uitgeverij Peeters.

Wolf, Kenneth Baxter. 2003. The Poverty of Riches: St. Francis of Assisi Reconsidered. New York: Oxford University Press, Inc.

Wolf, Kenneth Baxter. 2010. The Life and Afterlife of St. Elizabeth of Hungary (Testimony from her Canonization Hearings). Translated and Commentary by Kenneth Baxter Wolf. New York: Oxford University Press, Inc. 